\title{
AN EXPERIMENTAL ANALYSIS OF S.I ENGINE PERFORMANCE WITH HHO AS A FUEL
}

\author{
Dhananjay Babariya ${ }^{1}$, Jay Oza ${ }^{2}$, Bhavin Hirani ${ }^{3}$, Gaurang Akbari ${ }^{4}$ \\ ${ }^{1}$ Student, Mechanical Department, Babaria Institute of technology, Gujarat, India \\ ${ }^{2}$ Student, Mechanical Department, Babaria Institute of technology, Gujarat, India \\ ${ }^{3}$ Student, Mechanical Department, Babaria Institute of technology, Gujarat, India \\ ${ }^{4}$ Student, Mechanical Department, Babaria Institute of technology, Gujarat, India
}

\begin{abstract}
Alternate fuel is important and it should be fossil one. Actually we spend one third of our income for our vehicle fuelling and the vehicle gives harmful decomposed materials like $\mathrm{CO}, \mathrm{NO}, \mathrm{HC}, \mathrm{WCBSFC}$, etc. in the form of smoke. These materials are all affects the engine performance and pollutes the environment. Water is one of the free recourses and by applying the technique, it can be converted into hydrogen with oxygen, its chemical term is HHO and in general "Free Energy". To avoid these drawbacks, some level of $\mathrm{HHO}$ is mixed with filtered air, which is after the air filter system and before the engine in taken system of the vehicle. This mixed HHO ignites releasing the extra electrons into the igniting fuel and thus the added extra energy from the HHO leads cent percent of complete burning of the fuel. HHO is popular and common gas produced from electrolysis. The outcome get by this project is that there is increasing in mileage of the vehicles up to certain percentage according to their specification \& running condition of vehicle \& also there is a reduction of harmful decomposed material up to certain percentage. There is increasing in the engine lubricating oil life up to certain service timing \& there is also reduction in suspended carbon particles inside the engine combustion chamber. From the above description we can say that the fuel efficiency and vehicle performance are increased. The emissions of harmful and toxic gases are reduced up to some percentage. This is the safest method to give clean \& healthy environment to the next generation people by installing this HHO model in all two and four wheelers vehicles.
\end{abstract}

Keywords: S.I Engine (Spark Ignition), HHO-Brown's Gas, B.P, S.F.C, Emission flue gases-Co, H.C etc.

\section{INTRODUCTION}

This paper illustrates what is the effect of the partial inclusion of the HHO gas into the conventional S.I engine along with the petrol.

As we know that current global economy faces problems in the fossil fuels and fossil fuels end in the nearest future. Another reason is that, these fossil fuels are also harmful for the environment. It affects the protection layer of the earth i.e. Ozone layer as well as global warming effect \& green house effects.

Internal combustion engine in which the combustion of fuel takes place inside the cylinder is known as I.C engine, the procedure of combustion are directly the motive fluid. Petrol $\&$ Diesel engine are the examples of this type, where the working substance is the product of combustion.

The I.C engine can classified on the following basis

Working Cycle: Spark Ignition Engines \& Compression ignition Engines

No. Of Strokes: Two Stroke Engines \& Four Stroke Engines

In this project we are using Spark Ignition Four Stroke I.C Engine. BASIC WORKING OF Four Stroke Spark Ignition (S.I) Engine:
Mainly, S.I engine working fuel is petrol which also termed as Gasoline.

Petrol engine takes air and petrol mixture at required proposition which is taken into the intake manifold of an engine and ignited spark plug when the charge is compressed. The four stroke S.I engine was introduced in 1876 by Nicolaus August Otto.

Four stroke S.I engine has 4-stroke means two revolution of crank-shaft in which piston comes from T.D.C to B.D.C in suction stroke \& B.D.C to T.D.C in compression which one revolution of crankshaft. Then piston goes again T.D.C to B.D.C in combustion stroke where spark plug ignite the airfuel mixture and again piston moves B.D.C to T.D.C in exhaust stroke to exhaust the flue gases generated in combustion of air-fuel mixture which is one another revolution. So total two revolution of the crankshaft. 


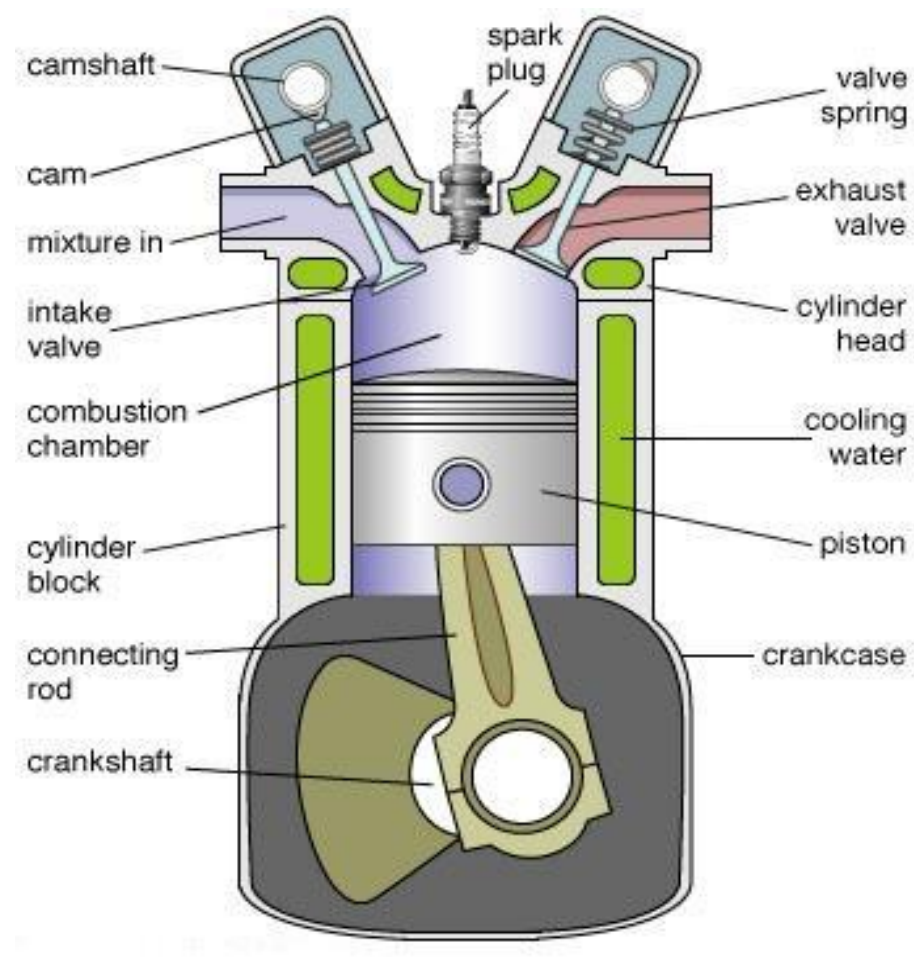

Fig 1 Four-stroke Spark Ignition Engine

\subsection{Desirable Properties of Good I.C Engine Fuel}

- High energy content per unit quantity of fuel.

- Good combustion properties.

- Availability in large quantities economically.

- $\quad$ Free from fire hazards.

- High stability with changes in temperature.

- Low pollution

- $\quad$ Easy to store \& transport.

- Products of combustion in gaseous form and noncorrosive.

\subsection{Conventional Fuels Used in I.C Engine:}

Basic conventional fuels used in I.C engine in nowadays are Petrol, Diesel, Liquefied Petroleum Gas (LPG), Compressed Natural Gas (CNG) etc.

PETROL: Gasoline or Petrol is a transparent, petroleumderived liquid. It consists mostly of organic compounds obtained by the factional distillation of petroleum, enhanced with a variety of additives. The quality of petrol as a fuel in I.C engines is measured by its octane rating.

DIESEL: Diesel fuel ignition takes place as a result of compression of the inlet air mixture and then injection of fuel. Diesel is a specific fractional distillate of petroleum fuel oil, but alternative that is not derived from petroleum, such as biodiesel, biomass to liquid diesel, are increasingly being developed and adopted. To distinguish these types, petroleum-derived diesel is increasingly called petro-diesel.

LPG: Liquefied Petroleum Gas, also referred to as simply propane or butane, is a flammable mixture of hydrocarbon gases. It is increasingly used as an I.C engine fuel, replacing harmful pollutants in an effort to reduce damage to the ozone layer. When specifically used as a vehicle fuel it is often called as auto gas.

CNG: Compressed nature gas can be used in place of Petrol, Diesel and Liquefied petroleum gas. CNG combustion produces fewer undesirable gases than the fuels mentioned above. CNG is made by compressing natural gas which is mainly composed of methane $\left(\mathrm{CH}_{4}\right)$. It is stored in hard containers at a pressure of $20-25 \mathrm{MPa}$, usually in cylindrical or spherical shapes. It is safer than other fuels in the event of a spill, because natural gas is lighter than air and disperses quickly when released.

\section{THEORETICAL BACKGROUND}

There is a mis-conception about the Hydrogen gas on the demand is burning hybrid hydrogen or HHO gas or Brown's gas along with gasoline or diesel and due to this reason there should be increasing in the MPG (Miles per Gallon). But it is different it says that, HHO gas is a supplement or as additive to conventional engine fuel system, it helps in combustion of the conventional engine fuels more efficiently \& effectively. HHO gas is also called as Brown's gas or oxy-hydrogen gas, it is water break in to two parts by the help of the electrolysis process of water, and hence it is two mole of hydrogen \& one mole of oxygen.

\subsection{Properties of HHO Gas}

There are many unique and unusual properties that HHO Gas possesses. Below is a list of some of the properties.

- Gas proves to be odorless, colorless and lighter than air.

- In the production of HHO Gas, there is no evaporation process at all, the electric energy used being insufficient for evaporation.

- The variable character of the energy content of HHO Gas is evidence that the gas has a unique structure with a chemical composition including bonds beyond those of valence type.

- HHO Gas does not follow the fundamental PVT Law for gases.

- HHO Gas demonstrates an anomalous adhesion to gases, liquids and solids. HHO Gas bonds to gaseous fuels (such as natural gas, magnegas fuel, and others) and also to liquid fuels (such as diesel, gasoline, liquid petroleum, and others).

- Santilli describes the creation of the gaseous and combustible HHO from distilled water at atmospheric temperature and pressure via a process structurally different than evaporation or separation, which suggests the existence of a new form of water.

- $\quad \mathrm{HHO}$ is described to have the structure $\mathrm{H}-\mathrm{O}-\mathrm{H}$ where represents the new molecular bond and the conventional molecular bond. The transition from the conventional $\mathrm{H}-\mathrm{O}-\mathrm{H}$ configuration to the new $\mathrm{H}-\mathrm{O}-\mathrm{H}$ species is explained as being a change of the electric polarization of water caused by the electrolyzes. 


\subsection{Production of Hydrogen}

Hydrogen is not a fuel that occurs free in nature like fossil fuel. Primary source of energy like solar, nuclear or hydroelectric is necessary to separate it from original combined state. The following methods are considered suitable for hydrogen production:

\section{Electrolysis of Water}

In this method, electrical energy is used to break water into $\mathrm{H}_{2}$ and $\mathrm{O}_{2}$. In principle, an electrolysis cell consists of two electrodes, commonly flat metal or carbon plates, immersed in an aqueous conducting solution called the electrolyte.

\section{Electrolysis: Splitting water with electricity to produce hydrogen and oxygen:}

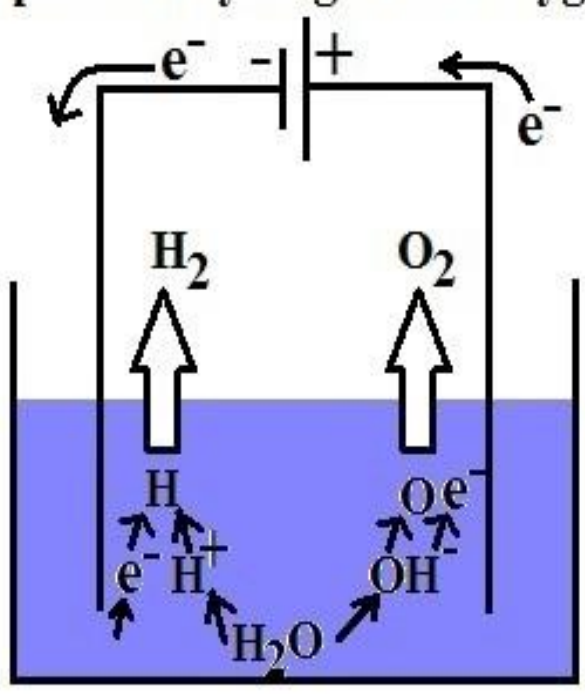

Fig 2 Electrolysis of water

A source of DC voltage connected to the electrodes so that an electric current flows through the electrolyte from anode to cathode. As a result, water in the electrolyte solution is decomposed into $\mathrm{H}_{2}$ which is released at the cathode and oxygen at the anode. Since water itself is the poor conductor of electricity an electrolyte like $\mathrm{KOH}$ is used increase the electric conduction.

\subsection{Safety In Utlization Of Hho}

- $\quad$ Biggest and very important safety point in using HHO is, it is only produced when an engine start. So it is termed as HHO on demand, its meaning is when the vehicle engine starts to run, then and then generator start the electrolysis process of water.

- $\quad \mathrm{HHO}$ is never store. The HHO gas would be aspirated directly to the engine intake process while the engine is in operation, thereby avoiding dangerous accumulation.

- A fuse should always be installed between electrolysis generator and power source; a fuse will protect from electrical shocks and possible wires burning. A fuse will also protect generator from getting too hot from high amp usage.

- Bubbler tanks in between generator and the air intake are essential for neutralizing catalyst contaminants. Also it will protect generator from flashbacks. It is always easier to replace a bubbler tank than a generator.

- $\quad$ For good HHO safety, it should never rely on a check valve alone for flashback protection.

- $\quad$ Stainless steel of the highest quality (S.S 316 \& 409) which can be affordable with all hardware specifications are used in electrolysis process, so no degradation of metals occur because electrolysis process don't able to degrade stainless materials.

\section{EXPERIMENTAL SET-UP \& ITS RESULT}

An experimental set-up line diagram is shown as below:

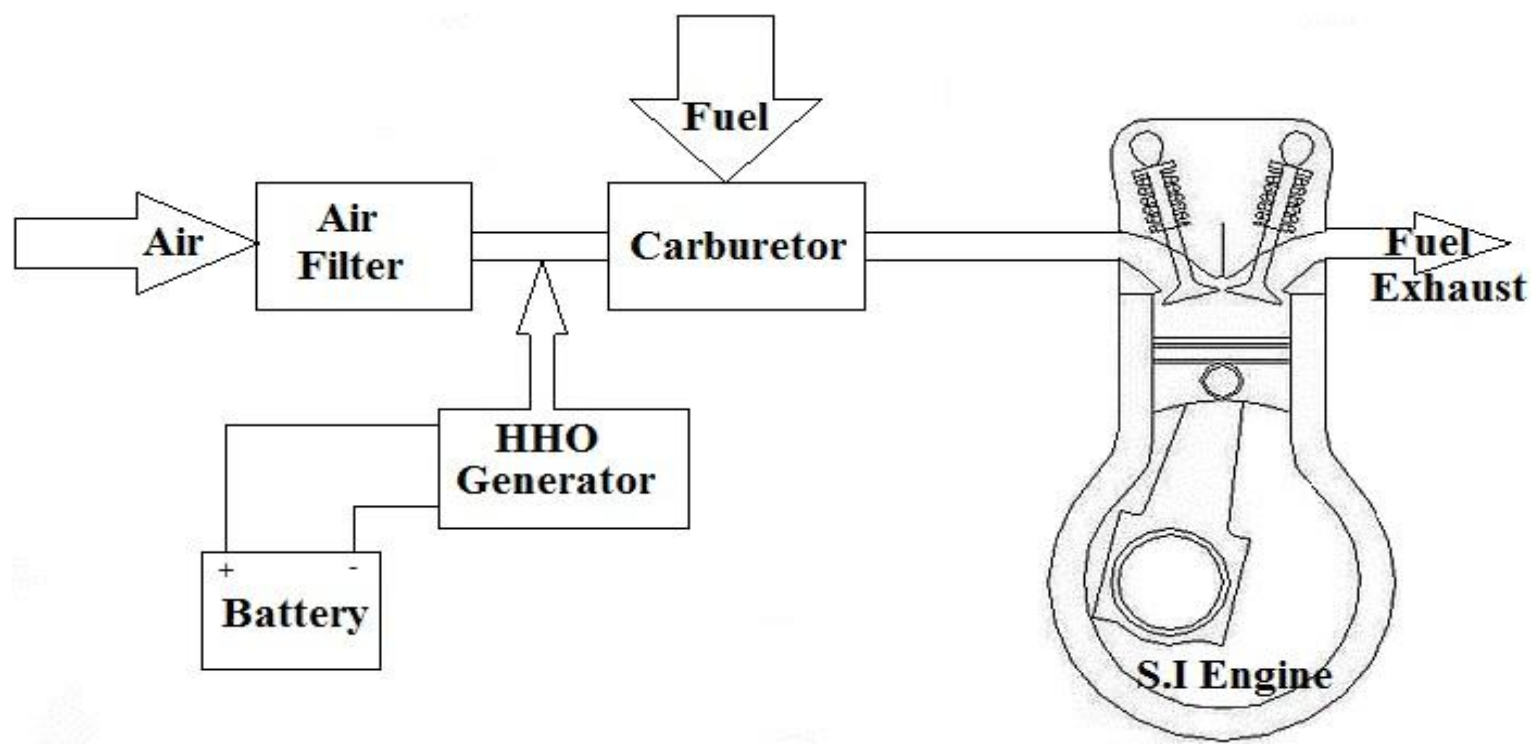

Fig 3 Line Diagram of Experimental Set-up 
A conventional S.I engine of Hero Honda Ambition bike of $135 \mathrm{cc}$ is used as an experiment. Hydrogen generation is carried out by the HHO generator which held the process of electrolysis of water with the help of the C.D.I (Capacitor Discharge Ignition) of the electric wiring of the engine. Using of CDI is just because of Ambition Bike C.D.I can sufficiently generate $12 \mathrm{~V}$ current which is required to carry out electrolysis process i.e. HHO generation process.

HHO generator is consists of two parts: First is container in which S.S plates of 316 grade are used to immerse in the water and second is control box from which generator is connected to the Battery i.e. in our case it is connected with C.D.I of an engine to execute the electrolysis of water. Water needed for this process is high quality water like D.M water or Distilled water or R.O water or we can also use water having low TDS says below 250-300PPM. The water used for this purpose is changed after $1000 \mathrm{kms}$. Or say after water color changes to maroon/red accent.

Following is the HHO generator we have used for this experiment: Fig. 4

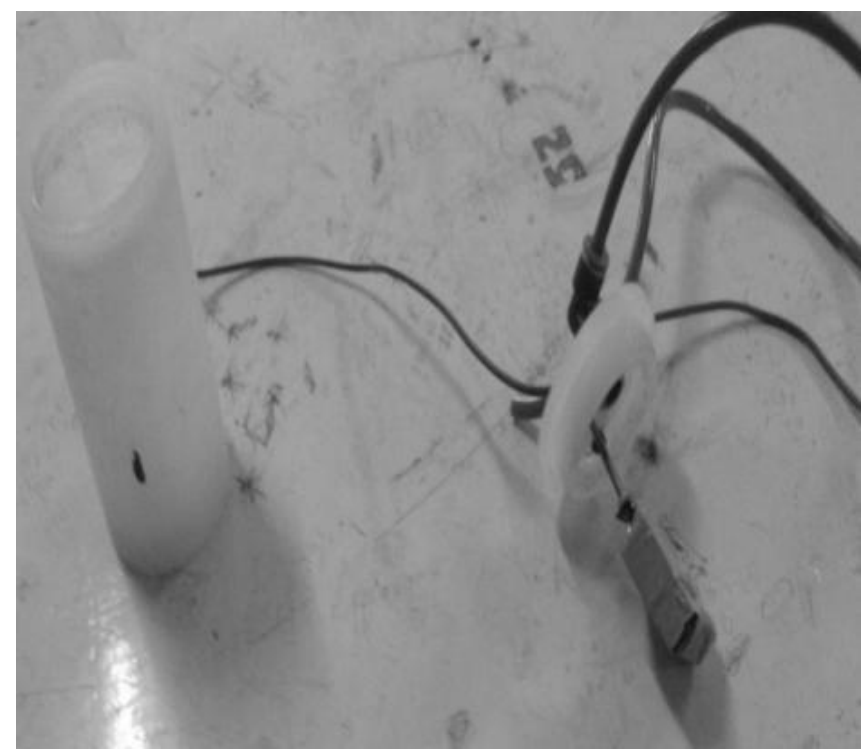

Fig 4 HHO generator
Following is the Experimental Set-up which we used to take experiments \& result analysis: Fig. 5

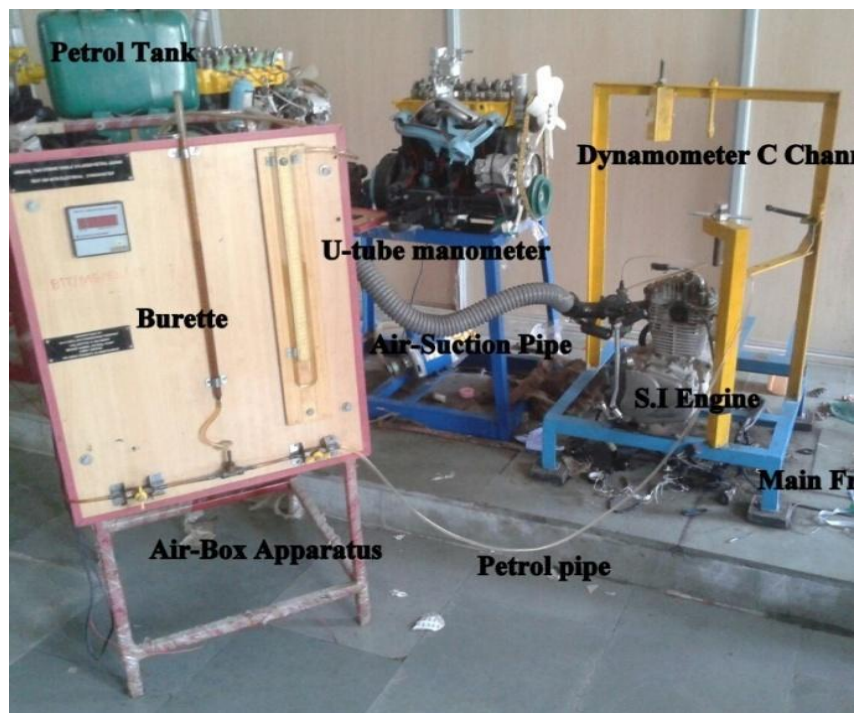

Fi 5 Experimental Set-Up

\subsection{Observation Table}

\begin{tabular}{|c|c|c|c|c|c|c|c|c|}
\hline \multicolumn{3}{|c|}{$\begin{array}{l}\text { Load } \\
(\mathrm{Kg})\end{array}$} & \multicolumn{6}{|c|}{ PETROL AS A FUEL } \\
\hline $\mathrm{S}_{1}$ & $\mathrm{~S}_{2}$ & $\mathrm{~S}_{1}-\mathrm{S}_{2}$ & $\begin{array}{l}\text { Drum } \\
\text { Speed } \\
\text { RPM } \\
\end{array}$ & $\begin{array}{l}\text { Engine } \\
\text { Speed } \\
\text { RPM }\end{array}$ & $\begin{array}{lr}\text { Time taken for } \\
10 \mathrm{cc} \\
\text { consumed }\end{array}$ & $\begin{array}{l}\text { B.P } \\
(\mathrm{KW})\end{array}$ & $\begin{array}{l}\text { Th } \\
(\%)\end{array}$ & $\begin{array}{l}\text { S.F.C } \\
(\mathrm{kg} / \mathrm{kW}-\mathrm{hr})\end{array}$ \\
\hline 25 & 6 & 19 & 271 & 1045 & 32 & 0.95 & 10.11 & 0.848 \\
\hline 25 & 6 & 19 & 598 & 2310 & 25 & 2.1 & 16.6 & 0.51 \\
\hline 25 & 5 & 20 & 806 & 3116 & 23 & 2.98 & 22.8 & 0.37 \\
\hline 25 & 5 & 20 & 1109 & 4287 & 22 & 4.1 & 29 & 0.295 \\
\hline 25 & 5 & 20 & 1406 & 5435 & 13 & 5.2 & 22.3 & 0.38 \\
\hline
\end{tabular}

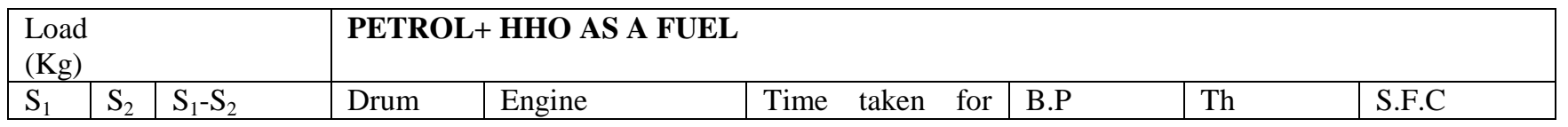




\begin{tabular}{|l|l|l|l|l|l|l|l|l|}
\hline & & $\begin{array}{l}\text { Speed } \\
\text { RPM }\end{array}$ & $\begin{array}{l}\text { Speed } \\
\text { RPM }\end{array}$ & $\begin{array}{l}10 \mathrm{cc} \text { fuel } \\
\text { consumed }\end{array}$ & $(\mathrm{KW})$ & $(\%)$ & $(\mathrm{kg} / \mathrm{kW}-\mathrm{hr})$ \\
\hline 25 & 6 & 19 & 302 & 1168 & 36 & 1.06 & 12.41 & 0.678 \\
\hline 25 & 6 & 19 & 641 & 2478 & 28 & 2.25 & 20.62 & 0.41 \\
\hline 25 & 5 & 20 & 866 & 3348 & 27 & 3.2 & 28.1 & 0.301 \\
\hline 25 & 5 & 20 & 1136 & 4392 & 25 & 4.2 & 34.3 & 0.245 \\
\hline 25 & 5 & 20 & 1487 & 5752 & 15 & 5.5 & 26.04 & 0.323 \\
\hline
\end{tabular}

\subsection{Result Table}

\begin{tabular}{|c|c|c|c|c|c|c|c|c|c|c|c|c|}
\hline \multirow{2}{*}{$\begin{array}{l}\text { Weight, } \\
\text { W (kg) }\end{array}$} & \multirow{2}{*}{$\begin{array}{l}\text { Spring } \\
\text { Balance } \\
\text { Reading, } \\
\text { S (kg) }\end{array}$} & \multirow{2}{*}{$\begin{array}{l}\text { Net } \\
\text { Load } \\
\text { on } \\
\text { Engine, } \\
\text { W-S } \\
(\mathrm{kg}) \\
\end{array}$} & \multirow{2}{*}{$\begin{array}{l}\text { Drum } \\
\text { Speed } \\
(\mathrm{rpm})\end{array}$} & \multirow{2}{*}{$\begin{array}{l}\text { Engine } \\
\text { Speed, } \\
\mathrm{N} \\
(\mathrm{rpm})\end{array}$} & \multicolumn{2}{|c|}{$\begin{array}{l}\text { Time taken for } \\
10 \mathrm{cc} \quad \text { fuel } \\
\text { consumed (Sec) }\end{array}$} & \multicolumn{2}{|c|}{$\begin{array}{l}\text { Brake Power, } \\
\mathrm{BP}(\mathrm{kW})\end{array}$} & \multicolumn{2}{|c|}{$\begin{array}{l}\text { Thermal } \\
\text { Efficiency, th } \\
(\%)\end{array}$} & \multicolumn{2}{|c|}{$\begin{array}{l}\text { Specific Fuel } \\
\text { Consumption, } \\
\text { SFC (kg/kW-hr) }\end{array}$} \\
\hline & & & & & $\begin{array}{l}\text { Petrol } \\
\text { Engine }\end{array}$ & $\begin{array}{l}\text { Petrol- } \\
\text { HHO } \\
\text { Engine }\end{array}$ & $\begin{array}{l}\text { Petrol } \\
\text { Engine }\end{array}$ & $\begin{array}{l}\text { Petrol- } \\
\text { HHO } \\
\text { Engine }\end{array}$ & $\begin{array}{l}\text { Petrol } \\
\text { Engine }\end{array}$ & $\begin{array}{l}\text { Petrol- } \\
\text { HHO } \\
\text { Engine }\end{array}$ & $\begin{array}{l}\text { Petrol } \\
\text { Engine }\end{array}$ & $\begin{array}{l}\text { Petrol- } \\
\text { HHO } \\
\text { Engine }\end{array}$ \\
\hline 25 & 6 & 19 & 271 & 1045 & 32 & 0.95 & 10.11 & 0.848 & 25 & 6 & 19 & 271 \\
\hline 25 & 6 & 19 & 302 & 1168 & 36 & 1.06 & 12.41 & 0.678 & 25 & 6 & 19 & 302 \\
\hline 25 & 5 & 20 & 806 & 3116 & 23 & 2.98 & 22.8 & 0.37 & 25 & 5 & 20 & 806 \\
\hline 25 & 5 & 20 & 866 & 3348 & 27 & 3.2 & 28.1 & 0.301 & 25 & 5 & 20 & 866 \\
\hline
\end{tabular}

\subsection{Result Graphs}

\subsubsection{Mechanical Performance Graphs:}

GRAPH I: Speed Vs. Thermal Efficiency: As the graph shows that, as speed increased thermal efficiency of the engine fuelled with petrol+HHO gives better result of performance.

Thermal Efficiency Vs.

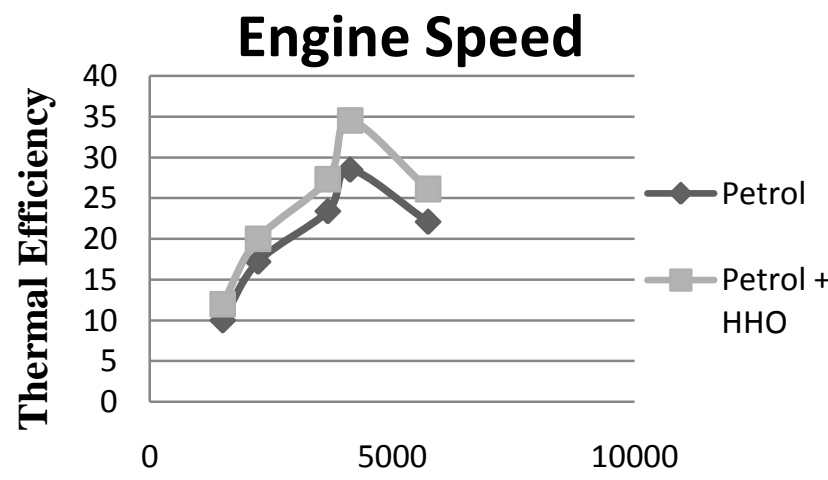

Engine Speed (R.P.M)

\section{S.F.C Vs. B.H.P}

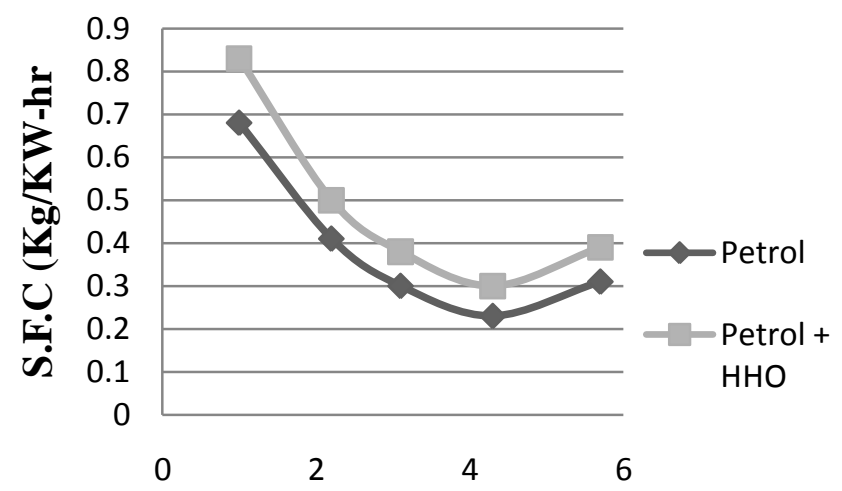

B.H.P (KW)

GRAPH III: Brake Horse Power Vs. Speed: As the graph shows that, when using $\mathrm{HHO}$ gas as a partial fuel power should be produce same as the in the petrol but it would get higher value of power in $\mathrm{HHO}$ gives better performance to the engine.

GRAPH II: Specific Fuel Consumption Vs. Brake Horse Power: As the graph shows that, when the specific fuel consumption decreases the brake power also decreased with S.F.C it state that HHO reduces the loss of power with specific fuel consumption. 


\section{B.H.P Vs. Engine Speed}

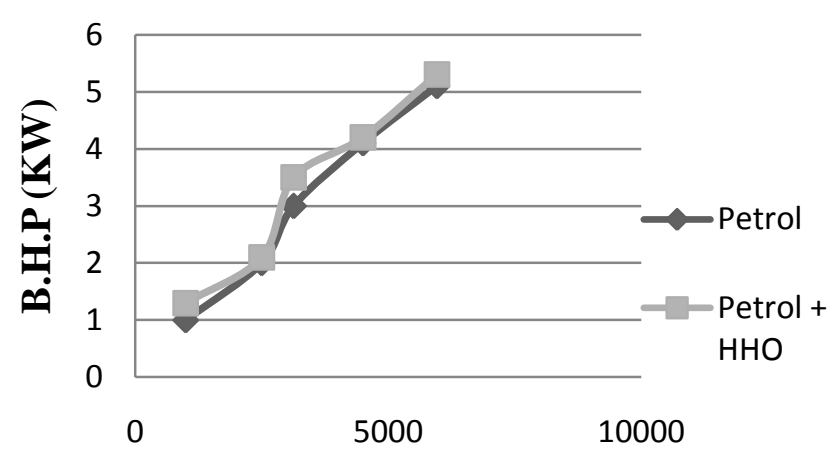

Engine Speed (RPM)

\subsubsection{Emission Performance Graphs}

Emission gases are generated in an engine when it is operated with a fuel-rich equivalence ratio. These emissions can be reduced by operating the engines at leaner ratios. $\mathrm{HHO}$ gas fuelled engine can be operated at leaner ratios, thus resulting in reduced level of $\mathrm{CO}_{2} \& \mathrm{HC}$ emissions. Graphs show the reduction in $\mathrm{CO}_{2} \& \mathrm{HC}$ emission level for gasoline with HHO gas fuel compared to that of gasoline fuel. This is because of the operation of the engine at lean ratios.

\section{$\mathrm{CO}_{2}$ Vs. B.H.P}

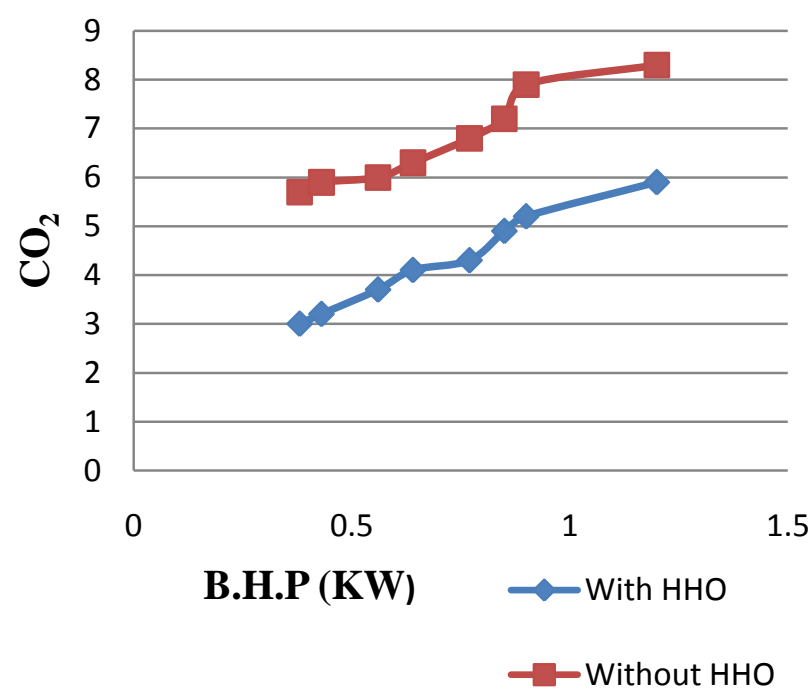

HC Vs. B.H.P

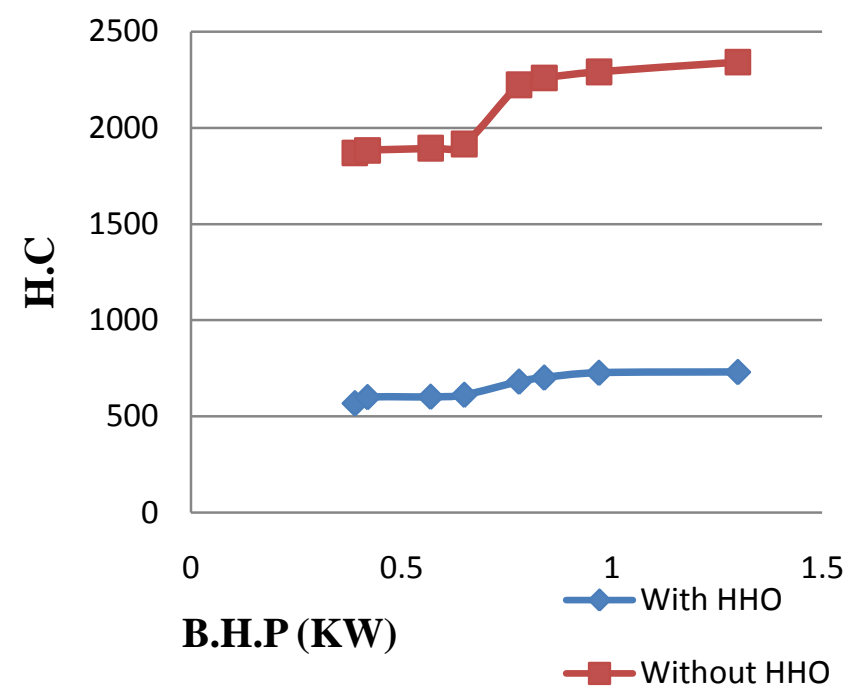

\section{CONCLUSION}

The Petrol engine performance and emission analysis are conducted with Petrol $+\mathrm{HHO}$ and petrol respectively. Thus the performance and emission analysis results are compared after conducting the tests with petrol on 'Reduction of fuel consumption in gasoline $+\mathrm{HHO}$ and petrol respectively. The following conclusions are observed as follows :

- The use of HHO in gasoline engines combustion efficiencies, consequently fuel consumption by $20 \%$.

- Use of HHO in gasoline engines leads to reduction in emission of harmful pollutants such as carbon monoxide and unburnt hydrocarbons.

- Use of HHO in gasoline engine increases the power output of the engine around $5.7 \%$.

- $\quad$ The HHO gas kit can be easily constructed and easily integrated with existing engines at low cost.

- Thermal Efficiency increases around 5\%

\section{ACKNOWLEDGEMENTS}

We have taken efforts in this research paper. However, it would not have been possible without the kind support and help of many individuals and organizations. We would like to extend our sincere thanks to all of them. We are highly indebted to Mr.Ratneshsir Parmar for their guidance and constant supervision as well as for providing necessary information regarding the project. We also thankful to our project co-guide Mr.Subhasissir Sarkar for their kind \& unconditional support in our hard time for making project working model. We are also thankful for the kind support given by our Workshop Assistant Mr. Suresh sir for given their effort to build-up this project

We would like to express our gratitude towards our parents \& member of BABARIA INST. OF TECH. for their kind co-operation and encouragement which helped us to introduce this new innovation in this competitive era. Apart 
from the efforts of our group, the success of this project depends largely on the encouragement and guidelines of many others. We take this opportunity to express our gratitude to the people who have been instrumental in the successful completion of this project.

Our thanks and appreciations also to our colleagues in developing the project and people who have willingly helped us out. The guidance and support received from all the team members who contributed and are contributing to this project, was vital for the success of the project. We are grateful for their constant support and help.

\section{REFERENCES}

[1]. "Effect of hydroxy (HHO) gas addition on performance and exhaust emission emissions in I.C engines". Article in International Journal of Hydrogen Energy, 2010, published by Ali Khan Yilmaz, Erinc Uludamar \& Kadir Aydin, Department of mechanical Engineering, Cukurova University, 01330 Adana, turkey. Article was published on $5^{\text {th }}$ July 2010.

[2]. "Reduction of fuel consumption in gasoline engines by introducing $\mathrm{HHO}$ gas into intake manifold". Article in International Journal of Hydrogen Energy 35, 2010, published by Ammar A. Al-Rousan, Department of mechanical engineering, Faculty of Engineering, Mutah, AlKarak 61710 Jordan. Article was published on $30^{\text {th }}$ august 2010.

[3]. "The performance, Exhaust Gas Emissions of Ethanol Gasoline Blended with HHO additive on a Spark ignition engine controlled by engine control unit without lamda sensor". Research paper was submitted in The 2012 International Conference on Green technology and Sustainable Development by Tran ThanhBinh, ImanKartolaksonoReksowardojo, Athol J.Kigour, and WinrantoAismunandar Lab for Combustion Engine and Propulsion System Institute Technology Bandung, Indonesia.

[4]. "HHO gas with Bio-Diesel as a dual fuel with Air Preheating technology". E-book in www.sciencedirect.com, published by R.B.Durairaj and J.Shanker, Faculty of engineering \& technology, SRM University, Chennai, India. As well as guided by Dr.M.Sivasankar, Professor and Director centre for bio medical research, Arunai engineering college, Thiruvanamalai, India.

[5]. Hand Book on "Effects of Various Fuel Blends on the Performance of a Two-stroke I.C engine" Vol.2. Authors of book are Stasa Puskaric, Rochester Institute of Technology, American College of Management and Technology, Don Frana Bulića, 20000 Dubrovnik and second author, Damir Oros, Department of Biochemical Engineering, Faculty of Food Technology and Biotechnology, University of Zagreb, Pierottijeva, HR-10000 Zagreb, Croatia. Corresponding author email stasa@actmt.hr. Vol.2 published in 2012.

[6]. "Effects of Browns gas performance and emission in a S.I engine". Journal published in International Journal of scientific \& engineering, Volume 4, issue 12, December 2013 - ISSN 2229-5518. Submitted \& researched by D.V.N.Lakshmi, T.R.Mishra, and R.Das \& S.S.Mohapatra.
[7]. "Improving Performance and reducing pollution emission of a carburetor gasoline engine by adding $\mathrm{HHO}$ gas into Intake Manifold". Journal was submitted in SAE International by Turan Le Anh, Khanh Nguyen Duc \& Huong Tran Thi Thu, Hanoi University of science \& technology and Tai Cao Van, Nha trang Vocational Training college. Journal number 2013-01-0104 TSAE-13AP-0104; published in 2013.

[8]. "Improvement of efficiency of operation of an internal combustion engine by using browns gas". Summary of Doctoral Dissertation, Technological Sciences, Transport Engineering, Vilnius, Lithuania. Doctoral dissertation was prepared at Vilinius Gedimias technical University on 2013. Scientific Supervisor Dr Saugirdas Pukalskas \& Chairman Dr.Habil Marijonas prepared a book on it.

[9]. "Improving the efficiency of I.C engine using secondary fuel". A journal published in International Journal of technology enhancements and emerging research, Volume 2, issue 6 ISSN 2347-4289 in 2014 by A.Vamshi Krishna reddy, T.Sharath Kumar, D.K.Tharun Kumar, b.Dinesh, Y.V.S.Saisantosh, Mechanical Department Malla Reddy College of Engineering, JNTUH, Hyderabad, India; 5Aeronautical Department Malla Reddy College of Engineering, JNTUH, Hyderabad, India. Email: vamsikrishna.avuthu@gmail.com.

[10]. "Experimental Analysis of Hydro Enhanced Automobile Engine". A journal published in International Journal of Emerging Technology and Advanced Engineering Website: www.ijetae.com (ISSN 2250-2459, ISO 9001:2008 Certified Journal, Volume 4, Issue 8, and in 2014) by Vikas Sonthalia, Mohan Radhesh Mallya, Aksah Sonthalia \& K.S.Sridhar, Department of mechanical engineering, PESIT,100ft. Ring road, Banashankari $3^{\text {rd }}$ stage, bengaluru-560085.

[11]. "Effect of $\mathrm{HHO}$ on four Stroke Petrol Engine Performance", a research paper submitted in $9^{\text {th }}$ South African Conference on Computational and Applied Mechanics Somerset West in 2014 by Daniel M. Madyira, Wayne G. Harding, Department of Mechanical Engineering Science, Faculty of Engineering \& the Built Environment, University of Johannesburg, Auckland Park 2006, Johannesburg. dmadyira@uj.ac.za

[12]. "Effect of Brown Gas on the Performance of a Four Stroke Gasoline Engine". A literature by both student Shrikant Bhardwaj, Student of Computer Aided Design Engineering, Krishna Institute of Engineering \& Technology, Uttar Pradesh Technical University, (U.P) India and faculties Ajay Singh Verma \& Subodh Kumar Sharma, associate Prof. Mechanical Dept. Krishna Institute of Engineering. \& Technology, Ghaziabad (U.P) submitted in International Journal of Emerging Technology and Advanced Engineering Website: www.ijetae.com (ISSN 2250-2459 (Online), Volume 4, Special Issue 1, February 2014) International Conference on Advanced Developments in Engineering and Technology (ICADET-14), INDIA.

[13]. National Aeronautics and Space Administration (NASA), Washington D.C. Report No. NASA TN D-8487, Authorized by John F. Cassidy on the topic of "Emissions and Total Energy Consumption of a Multicylinder piston engine running on gasoline and a Hydrogen-Gasoline 
Mixture". It is an experimentation, which was held by the well-known aeronautics center in United States of America $\&$ published an article and journal.

[14]. A book by Bansal publications on "Fuels of I.C engines \& their properties". Chapter 1 to 3 .

[15]. A book on "Internal Combustion Engine" by Domkundwar; from chapter 1 to chapter 5.

[16]. A book on "Science behind water4gas by www.water2gas.com.

[17]. http://www.blulabresearch.org/wpcontent/uploads/2013/07/2011_Effect-of-HHO-gas-on-

combustion-emissions-in-gasoline-engines_S.A.Musmar-etal.pdf

[18]. A book for "Air Pollution from Motor Vehicles: Standards and Technologies for Controlling Emissions" by Asif Faiz, Christopher S. Weaver, Michael P. Walsh.

\section{BIOGRAPHIES}

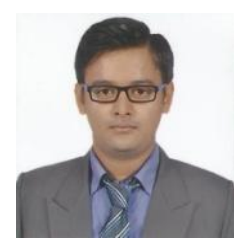

Dhananjay Babariya, Student of mechanical engineering at Babaria institute of technology, Varnama, Vadodara, Gujarat-India. He is in last year of mechanical department, passing out his graduation in May-2015.

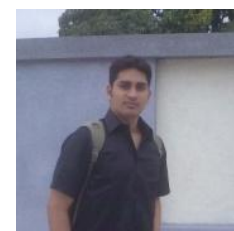

Jay Oza, Student of mechanical engineering at Babaria institute of technology, Varnama, Vadodara, GujaratIndia. He is in last year of mechanical department, passing out his graduation in May-2015.

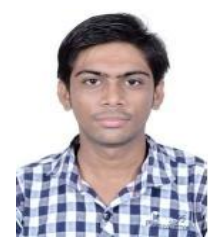

Bhavin Hirani, Student of mechanical engineering at Babaria institute of technology, Varnama, Vadodara, GujaratIndia. $\mathrm{He}$ is in last year of mechanical department, passing out his graduation in May-2015.

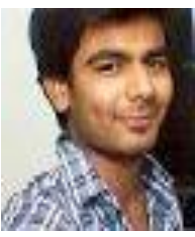

Gaurang Akbari, Student of mechanical engineering at Babaria institute of technology, Varnama, Vadodara, GujaratIndia. $\mathrm{He}$ is in last year of mechanical department, passing out his graduation in May-2015. 